\title{
Indapamide-Induced Prevention of Myocardial Fibrosis in Spontaneous Hypertension Rats Is Not Nitric Oxide-Related
}

\author{
P. JANEGA ${ }^{1,2}$, S. KOJŠOVÁ ${ }^{2}$, L. JENDEKOVÁ ${ }^{2}$, P. BABÁL $^{1}$, O. PECHÁŇOVÁ ${ }^{2,3}$ \\ ${ }^{I}$ Department of Pathology, Faculty of Medicine, Comenius University, ${ }^{2}$ Institute of Normal and \\ Pathological Physiology and Centrum of Excellence for Cardiovascular Research, Slovak Academy \\ of Sciences, Bratislava, Slovak Republic and ${ }^{3} C R C$ and Institute of Physiology, Czech Academy of \\ Sciences, Prague, Czech Republic
}

Received September 10, 2007

Accepted September 26, 2007

\begin{abstract}
Summary
We studied the effect of thiazide-like diuretic - indapamide on fibrosis development in the left ventricle of young spontaneously hypertensive rats (SHR) and assessed the involvement of nitric oxide in this process. Six-week-old male SHR were treated with indapamide $(1 \mathrm{mg} / \mathrm{kg} /$ day) for six weeks. Age-matched SHR were used as hypertensive and Wistar-Kyoto rats (WKY) as normotensive control. Systolic blood pressure was measured by tail-cuff plethysmography. Nitric oxide synthase (NOS) activity, protein expressions of endothelial (eNOS) and inducible NOS (iNOS), myocardial fibrosis and collagen type I and III were determined in the left ventricle. Indapamide treatment partially prevented SBP increase in SHR (SHR+Indapamide: 157 \pm , SHR: 171 \pm 3 , WKY: $119 \pm 3 \mathrm{mmHg}$ ). Indapamide prevented myocardial fibrosis development in SHR, but without affecting collagen type I to type III ratio. Indapamide did not affect NOS activity as well as eNOS and iNOS protein expressions in the left ventricles evaluated by both Western blot and immunohistochemically. In conclusion, our results indicate that indapamide-induced prevention of myocardial fibrosis is not mediated by nitric oxide-related mechanism.
\end{abstract}

\section{Key words}

Spontaneous hypertension $\bullet$ Myocardial fibrosis $\bullet$ Nitric oxide $\bullet$ Indapamide

Remodeling of cardiovascular system is one of the important factors leading to cardiovascular morbidity and mortality caused by the hypertensive disease. The effect of long-term hypertension is accompanied by structural and morphological changes of the heart tissue, characterized by loss of myocytes and an increase of diffuse and perivascular fibrosis. The morphological changes represent one of the key factors in the development and progression of chronic heart failure (Brilla et al. 1996).

The regulation of extracellular matrix composition seems to be crucial in these processes. It is based on the balance between the production and deposition of extracellular proteins and their degradation. 
Several studies have demonstrated that drugs with diuretic effect may influence extracellular protein metabolism (Contard et al. 1993, Kojšová et al. 2006). Some experimental studies reported the close connection between the extracellular matrix regulation and the activation of NO-moderated signaling pathways in the cells (Kim et al. 1999). However, the interpretation of the role of nitric oxide in these processes remains controversial.

The present study evaluated the involvement of $\mathrm{NO}$ in the indapamide-mediated prevention of spontaneous hypertension and heart remodeling. The effect of indapamide, a thiazide-like diuretic, on myocardial fibrosis formation and collagen types I and III proportion was investigated particularly.

Six-week-old spontaneously hypertensive rats (SHR) were randomly divided into two groups $(n=6$ in each group): SHR group and SHR group receiving indapamide in the dose of $1 \mathrm{mg} / \mathrm{kg}$ /day in the drinking water during 6 weeks. The age-matched Wistar-Kyoto rats $(n=6)$ without indapamide treatment were taken as normotensive controls. The rats were housed at $22 \pm 2{ }^{\circ} \mathrm{C}$ under a 12-hour light/dark cycle with access to standard pellet diet ad libitum.

Systolic blood pressure (SBP) was measured by a non-invasive method of tail-cuff plethysmography every week of the experiment. After 6 weeks of treatment, the animals were sacrificed and the body weight $(\mathrm{BW})$ and left ventricle weight (LVW) were determined. The left ventricle weight/body weight (HW/BW) ratio was calculated.

Total NOS activity was determined in crude homogenates of left ventricle tissue by measuring the formation of $\left[{ }^{3} \mathrm{H}\right]$-L-citrulline from $\left[{ }^{3} \mathrm{H}\right]$-L- arginine. For Western blot analysis, samples of the left ventricle were used and probed with polyclonal rabbit anti-eNOS and anti-iNOS antibodies (Alexis Biochemicals, Germany) as described elsewhere (Pecháňová et al. 2007). Formalinfixed and paraffin-embedded samples of the left ventricle were used for immunohistochemistry of endothelial and inducible NO-synthase protein expression following the technique described elsewhere (Paulis et al. 2007).

Modified picrosirius red staining technique by Dolber and Spach (1993) was used to determine fibrosis level. The sections were evaluated by light microscopy in polarized light at 40x magnification and the evidence of total fibrosis, collagen type I rich areas (red-yellow color in polarized light) and collagen type III rich areas (green color in polarized light) was measured by histomorpho-
Table 1. Systolic blood pressure (SBP), body weight (BW), left ventricle weight (LVW), LVW/BW ratio, nitric oxide synthase (NOS) activity, fibrosis and collagen type I to type III ratio in the left ventricle of Wistar-Kyoto rats (WKY), spontaneously hypertensive rats (SHR) and SHR treated with indapamide.

\begin{tabular}{lccc}
\hline & WKY & SHR & $\begin{array}{c}\text { SHR + } \\
\text { Indapamide }\end{array}$ \\
\hline $\begin{array}{l}S B P \\
(m m H g)\end{array}$ & $119 \pm 3$ & $171 \pm 3^{*}$ & $154 \pm 4^{* \#}$ \\
$\begin{array}{l}\text { BW } \\
(g)\end{array}$ & $339 \pm 6$ & $241 \pm 4 *$ & $244 \pm 2 *$ \\
$\begin{array}{l}\text { LVW } \\
\text { (mg) }\end{array}$ & $532 \pm 19$ & $508 \pm 18$ & $516 \pm 21$ \\
$\begin{array}{l}\text { LWV/BW } \\
\text { (mg/g) }\end{array}$ & $1.56 \pm 0.06$ & $2.11 \pm 0.0^{*}$ & $2.12 \pm 0.08^{*}$ \\
$\begin{array}{l}\text { NOS activity } \\
\text { (pmol/min/mg) }\end{array}$ & $1.2 \pm 0.1$ & $2.1 \pm 0.3^{*}$ & $2.6 \pm 0.3^{*}$ \\
$\begin{array}{l}\text { Heart tissue } \\
\text { fibrosis (\%) }\end{array}$ & $1.36 \pm 0.05$ & $2.1 \pm 0.13^{*}$ & $1.5 \pm 0.14^{\#}$ \\
$\begin{array}{l}\text { Collagen type I } \\
\text { to type III ratio }\end{array}$ & $1.55 \pm 0.21$ & $1.75 \pm 0.10$ & $1.57 \pm 0.10$ \\
\hline
\end{tabular}

Data are means \pm S.E.M., Significant differences: $* \mathrm{P}<0.05$ compared to WKY, ${ }^{\#} \mathrm{P}<0.05$ compared to untreated SHR.

metry in 10 microscopic fields using the ImageJ morphometric software v.1.33 (National Institute of Health, USA) and was expressed as a percentage of collagen positivity in total area of the microscopic field.

Results are expressed as means \pm S.E.M. Oneway analysis of variance was used for statistical analysis. Values were considered to differ significantly if the probability value was less than $0.05(\mathrm{p}<0.05)$.

SBP and LVW/BW ratio in the SHR group was increased significantly in comparison with Wistar-Kyoto rats. Chronic indapamide treatment partially prevented blood pressure increase in SHR, but it failed to affect LVW/BW ratio in SHR (Table 1).

NO synthase activity in the left ventricle of SHR was increased significantly when compared to WistarKyoto rats and chronic indapamide treatment did not affect this activity (Table 1). Similarly, indapamide treatment had no effect on both eNOS and iNOS expression in the left ventricle of SHR analyzed by Western blot. Both types of NOS, endothelial and inducible, were present in myocardial cells showing moderate, fine granular cytoplasmic positivity. Part of myocytes did not show any NOS positivity. No 

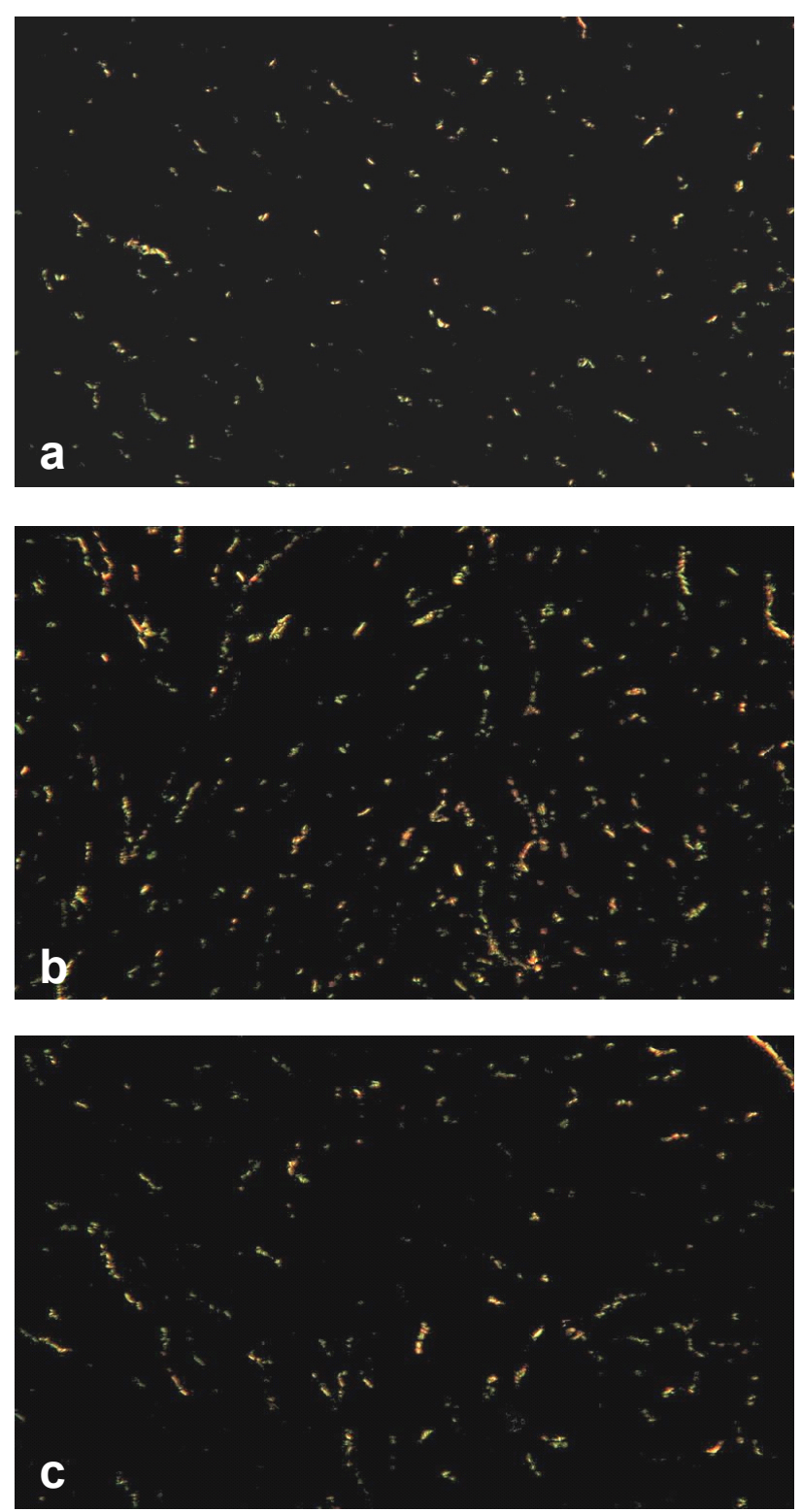

Fig. 1. Myocardial fibrosis in the left ventricle. Control WKY (a). Increased fibrosis in the myocardium of SHR (b) and indapamide-induced partial prevention of fibrosis in myocardium of SHR (c). Picrosirius red, polarized light. 400x.

differences in the localization of the positivity between SHR and SHR treated with indapamide were observed. The endothelial cells showed regular eNOS expression in both SHR and SHR treated with indapamide.

The diffuse and perivascular fibrosis was found in the left ventricle of SHR. The indapamide treatment significantly reduced the area of fibrosis in SHR to the level found in control Wistar-Kyoto rats (Fig 1, Table 1). No differences of the collagen type I to collagen type III ratio in left ventricle of all groups were found (Table 1). The results of the present study document that the administration of indapamide in early stages of spontaneous hypertension prevents the enlargement of myocardial fibrosis. Results indicating the protective effect followed by the normalization of functional changes of vessels were already reported in other studies, which used the combination of indapamide with various ACE inhibitors treatment (Doucet et al. 2001, Ibrahim et al. 1999). The mechanism of this effect is still not completely elucidated. This study documented that indapamide may prevent myocardial fibrosis enlargement without increasing production of nitric oxide.

The imbalance between NO production and free radicals formation in the tissues participates in the development of structural and functional changes of cardiovascular system in SHR. This factor is especially important in the early stages of hypertension. Once the secondary alterations and structural remodeling had been formed, it accelerates the cardiovascular damage (Pecháňová et al. 2006, Pecháňová and Šimko 2007). Indapamide was shown to inhibit the contractile responses induced by norepinephrine and arginine vasopressin in the SHR aortic preparations via an endothelium-dependent mechanism (Colas et al. 2000). Our results do not indicate a significant effect of indapamide on NO production in the left ventricle. However, the participation of antioxidant properties of indapamide cannot be excluded. Indapamide differs chemically from the thiazides because it contains only one sulfonamide group and no thiazide ring. This gives the indapamide specific antioxidant properties. In our previous experiments, chronic indapamide treatment of SHR prevented the decrease of conjugated dienes in the kidney (Kojšová et al. 2006). Uehara et al. (1990) documented indapamide-induced reduction of malondialdehyde formation in the rat brain. Similarly, the major metabolite of indapamide - 5-OH indapamide was found to act as a potent free radical scavenger (Vergely et al. 1998).

The direct indapamide effect on the enzymes involved in the regulation of extracellular matrix composition (especially matrix metalloproteinases and their tissue inhibitors) can not be excluded as well. Anyway, in our study no differences in the ratio of collagen types between the groups were found. The activation of matrix metalloproteinases usually leads to the change of collagen types ratio due to different affinity of various metalloproteinases to various types of collagen. This fact indicates that other mechanisms will participate in the modification of the extracellular matrix composition during the indapamide treatment. 
In conclusion, indapamide induced decrease of myocardial fibrosis with no evidence of nitric oxide involvement. Antioxidant properties of indapamide are suggested to be involved in this beneficial effect.

\section{Acknowledgements}

The study was supported by VEGA 2/6148/26, 1/3429/06 and APVT 51-017905, APVV-0586-06.

\section{References}

BRILLA CG, MURPHY RL, SMITS JF, STRUIJKER BOUDIER HA, TAN LB: The concept of cardioreparation: Part 1. Pathophysiology of remodelling. J Cardiovasc Risk 3: 281-285, 1996.

COLAS B, SLAMA M, MASSON H, COLAS JL, COLLIN T, ARNOULD ML, HARY L, SAFAR M, ANDREJAK M: Direct vascular actions of methyclothiazide and indapamide in aorta of spontaneously hypertensive rats. Fundam Clin Pharmacol 14: 363-368, 2000.

CONTARD F, GLUKHOVA M, MAROTTE F, NARCISSE G, SCHATZ C, SWYNGHEDAUW B, GUEZ D, SAMUEL JL, RAPPAPORT L: Diuretic effects on cardiac hypertrophy in the stroke prone spontaneously hypertensive rat. Cardiovasc Res 27: 429-434, 1993.

DOLBER PC, SPACH MS: Conventional and confocal fluorescence microscopy of collagen fibers in the heart. J Histochem Cytochem 41: 465-469, 1993.

DOUCET J, RICHARD V, MULDER P, HENRY JP, SCHIAVI P, GUEZ D, THUILLEZ C: Effects of combination of low doses of angiotensin-converting enzyme inhibitor and diuretics on renal function in spontaneously hypertensive rats: comparison between acute and chronic treatment. $J$ Renin Angiotensin Aldosterone Syst 2: 107-111, 2001.

IBRAHIM J, SCHACHTER M, HUGHES AD, SEVER PS: Low dose indapamide plus perindopril combination effects on cardiovascular structure and function in genetic hypertension. Clin Exp Pharmacol Physiol 26: 622-7, 1999.

KIM NN, VILLEGAS S, SUMMEROUR SR, VILLARREAL FJ: Regulation of cardiac fibroblast extracellular matrix production by bradykinin and nitric oxide. J Mol Cell Cardiol 31: 457-466, 1999.

KOJŠOVÁ S, JENDEKOVÁ L, ZICHA J, KUNEŠ J, ANDRIANTSITOHAINA R, PECHÁŇOVÁ O: The effect of different antioxidants on nitric oxide production in hypertensive rats. Physiol Res 55 (Suppl 1): S3-S16, 2006.

PAULIS L, VAŽAN R, ŠIMKO F, PECHÁŇOVÁ O, STYK J, BABÁL P, JANEGA P: Morphological alterations and NO-synthase expression in the heart after continuous light exposure of rats. Physiol Res $\mathbf{5 6}$ (Suppl 2): in press, 2007.

PECHÁŇOVÁ O, ŠIMKO F: The role of nitric oxide in the maintenance of vasoactive balance. Physiol Res 56 (Suppl 2): in press, 2007.

PECHÁŇOVÁ O, ZICHA J, KOJŠOVÁ S, DOBEŠOVÁ Z, JENDEKOVÁ L, KUNEŠ J: Effect of chronic Nacetylcysteine treatment on the development of spontaneous hypertension. Clin Sci (Lond) 110: 235-242, 2006.

PECHÁŇOVÁ O, ZICHA J, PAULIS L, ZENEBE W, DOBESOVÁ Z, KOJŠOVÁ S, JENDEKOVÁ L, SLÁDKOVÁ M, DOVINOVÁ I, ŠIMKO F, KUNEŠ J.: The effect of N-acetylcysteine and melatonin in adult spontaneously hypertensive rats with established hypertension. Eur J Pharmacol 561: 129-136, 2007.

UEHARA Y, SHIRAHASE H, NAGATA T, ISHIMITSU T, MORISHITA S, OSUMI S, MATSUOKA H, SUGIMOTO T: Radical scavengers of indapamide in prostacyclin synthesis in rat smooth muscle cell. Hypertension 15: 216-224, 1990.

VERGELY C, WALKER MK, ZELLER M, RADEMAKERS JR, MAUPOIL V, SCHIAVI P, GUEZ D, ROCHETTE L: Antioxidant properties of indapamide, 5-OH indapamide and hydrochlorothiazide evaluated by oxygen-radical absorbing capacity and electron paramagnetic resonance. Mol Cell Biochem 178: 151-155, 1998.

\section{Corresponding author}

P. Janega, Department of Pathology, Faculty of Medicine, Comenius University, Sasinkova 4, 81372 Bratislava, Slovak Republic. Fax: 421259357 592. E-mail: pavol.janega@fmed.uniba.sk 